\title{
Partitioning of benthic community respiration in the Arctic (northwestern Barents Sea)*
}

\author{
D. Piepenburg ${ }^{1}$, T. H. Blackburn ${ }^{2}$, C. F. von Dorrien ${ }^{1}$, J. Gutt ${ }^{3}$, P. O. J. Hall ${ }^{4}$, \\ S. Hulth ${ }^{4}$, M. A. Kendall ${ }^{5}$, K. W. Opalinski ${ }^{6}$, E. Rachor ${ }^{3}$, M. K. Schmid ${ }^{1}$ \\ ${ }^{1}$ Institut für Polarökologie, Universität Kiel, Wischhof́str. 1-3, Geb. 12, D-24148 Kiel, Germany \\ ${ }^{2}$ Biological Institute, Department of Microbial Ecology, University of Aarhus, Ny Munkgade, DK-8000 Aarhus C, Denmark \\ ${ }^{3}$ Alfred-Wegener-Institut für Polar- und Meeresforschung, D-27515 Bremerhaven, Germany \\ ${ }^{4}$ Department of Analytical and Marine Chemistry, University of Göteborg, S-41296 Göteborg, Sweden \\ ${ }^{5}$ Plymouth Marine Laboratory, Prospect Place, Plymouth PL1 3DH, United Kingdom \\ ${ }^{6}$ Institute of Ecology of the Polish Academy of Sciences, Dziekanow Lesny, PL-05092 Lomianki, Poland
}

\begin{abstract}
For marine benthos communities, the assessment of a respiration budget encompassing the entire size range from microbes to mobile megafauna has seldom been attempted. An interdisciplinary field study in high Arctic waters (northwestern Barents Sea) in June/July 1991 provided the opportunity to concurrently estimate the oxygen uptake of the different benthic community fractions by a variety of approaches at water depths of 80 to $1010 \mathrm{~m}$. The bulk respiration of micro-, meio- and small macrobenthos was assessed by sediment community oxygen consumption (SCOC) rates measured by shipboard sediment-water incubations of virtually undisturbed cores. The oxygen uptake of community portions not sampled adequately by corers (megabenthic in- and epifauna, including fish) was estimated by applying individual metabolic rates to density or biomass figures derived from seabed images, box corer samples or trawl catches. The respiration estimates of the various community fractions were subsequently compiled in synoptic models of the total benthic community oxygen consumption (BCOC) and its partitioning. In the study area, 2 benthic habitat types were distinguished, differing substantially in depth, sediment texture and, thus, benthic respiration pattern: (1) shallow shelf banks $(<200 \mathrm{~m})$ where the seabed is composed of coarse sediments and stones, and (2) deeper trenches or slopes $(>200 \mathrm{~m}$ ) characterized by fine sediments. On the banks, the patchiness of epibenthic brittle stars, which locally occurred in very high densities (up to 700 ind $\mathrm{m}^{-2}$ ), controlled the benthic community respiration. On average, the megafauna was estimated to contribute about $25 \%$ to the median BCOC of about $90 \mu \mathrm{mol} \mathrm{O} \mathrm{m}^{-2} \mathrm{~h}^{-1}$ lequivalent to an organic carbon mineralization rate of $21 \mathrm{mg} \mathrm{C} \mathrm{m}^{-2}$ $\mathrm{d}^{-1}$ ). In the shelf trenches and on the slope, however, smaller endobenthic organisms predominated. SCOC, according to our estimates of meio- and macrofaunal respiration, was dominated by the oxygen uptake of microorganisms and accounted for about $85 \%$ of the median BCOC of about $140 \mu \mathrm{mol} \mathrm{O}_{2} \mathrm{~m}^{-2}$ $\mathrm{h}^{-1}$ (35 $\mathrm{mg} \mathrm{C} \mathrm{m} \mathrm{C}^{-2} \mathrm{~d}^{-1}$ ). Our results suggest that current models of benthic community respiration should be amended, particularly for Arctic shelf biotopes where abundant megafauna may represent an important pathway of the benthic energy flow.
\end{abstract}

KEY WORDS: Benthos - Sediment community - Megafauna - Respiration partitioning - Barents Sea Arctic

\section{INTRODUCTION}

The energy flow through benthic communities has been estimated in numerous studies by incubating sediment cores and following the decrease of dissolved oxy-

-AWI Publication No. 862 gen in the ambient water with time (Smith \& Hinga 1983). These measurements - whether performed in situ with benthic landers (e.g. Smith 1974) or using shipboard techniques (e.g. Hulth et al. 1994) - provide a bulk parameter integrating the chemical oxygen uptake plus the aerobic respiration of benthic organisms contained in the core sample. The values derived by this approach are used to assess the so-called sediment com- 
munity oxygen consumption (SCOC). The cores used for sediment-water incubations are usually rather small and cover only modest sample areas $\left(<500 \mathrm{~cm}^{2}\right)$. Therefore, they normally contain organisms ranging in body size from micro-, meio- to small macrobenthos (for definitions see e.g. Gage \& Tyler 1991). Mobile epibenthic or sessile endobenthic animals which are large enough to be seen in bottom images or to be caught by trawls ('megafauna'; Gage \& Tyler 1991) are, however, only very rarely included in those cores. Thus, SCOC measurements do not represent the total benthic commmunity oxygen consumption (BCOC) which encompasses, in addition to the $\mathrm{SCOC}$, the respiration of megabenthic epi- and endofaunal organisms.

The assembly of benthic oxygen flux budgets, covering various sizes and modes of life of organisms, and the modelling of its partitioning has been attempted in only a few studies (e.g. Dye 1981, Asmus 1982, Smith 1983, Gerlach et al. 1985, Schwinghamer et al. 1986, Grant \& Schwinghamer 1987, Smith et al. 1987), because this task demands the concomitant use of a variety of sampling techniques and analytical methods. The vast majority of those investigations have been performed in coastal areas of boreal latitudes which are easily accessible. The share of the different size groups, ranging from bacteria to endobenthic macrofauna, in the benthic oxygen uptake has been assessed by several approaches, involving both direct measurements and various estimation techniques. However, only very rarely has the megafauna been explicitly considered in such studies (Smith 1983, Smith et al. 1987). The oxygen flux entering this pathway cannot be measured directly like SCOC, but has to be computed by combining individual respiration rates with abundance or biomass figures derived by adequate sampling or observing methods. In some marine biotopes, however, megafaunal. species occur in high abundances, suggesting that they may, at least locally, have a significant but largely unknown share of the total benthic oxygen consumption (Grant et al. 1991).

A clear need existed for a case study to collect data on oxygen consumption by all parts of the benthic size spectrum. This was met by an interdisciplinary study ('Study of European Arctic Shelf', SEAS) during a cruise of the German RV 'Polarstern' ('European Polarstern Study II', EPOS II) to the northern Barents Sea in 1991, when the respiration of the different benthos fractions, such as the sediment community, megabenthic endo- and epifauna and fish (i.e. the oxygen fluxes through different BCOC pathways), could be assessed, each by an adequate method. Current knowledge of the benthos off Svalbard is comparatively scarce with respect to both stock sizes and oxygen uptake rates of the various benthic commmunity compartments. Quantitative inventories of the benthos have been confined to intertidal and sublittoral areas, mostly along the coasts of West and South Spitsbergen (Ambrose \& Leinaas 1988, Kendall \& Aschan 1993. Weslawski et al. 1993). Offshore studies in the Barents Sea east of Svalbard, which is particularly difficult to reach due to the perennial ice cover, have been conducted by Russian researchers (for a summary see Zenkevitch 1963) and Pfannkuche \& Thiel (1987). Information on the individual respiration rates of dominant mega- and macrobenthic species from Arctic or sub-Arctic waters is rather fragmentary. Only some species, e.g. crustaceans (Opalinski \& Weslawski 1989a, b, Opalinski \& Klekowski 1992), brittle stars (Wintzell 1918) and fish (Scholander et al. 1953, Holeton 1974), have been studied. Biogeochemical studies involving $\mathrm{SCOC}$ measurements have also been rare in ice-covered Arctic waters. Pfannkuche \& Thiel (1987) reported figures for sediment oxygen uptake from the Nansen Basin and the shelf northeast of Svalbard, Blackburn (1987) from the Chukchi Sea, Grebmeier \& McRoy (1989) from the Bering Sea, Grant et al. (1991) from the Labrador Sea, and Hulth et al. (1994) from the area around Svalbard.

This paper presents an attempt to compile generalized budgets of total benthic community respiration by synthesizing the results of our assessments of the aerobic respiration of various community fractions in the northwestern Barents Sea. The study area is characterized, however, by a considerable range in the environmental setting (water depths, seabed characteristics and water mass properties), causing a spatial variability of benthic community patterns and, thus, certainly also of $\mathrm{BCOC}$ and its partitioning. As station time was generally limited during EPOS II and environmental constraints prevented the use of certain gears at some sites, it was not feasible to employ the whole suite of methods (corers, trawls, seabed photography), used to sample the various benthic community portions, concomitantly at any station. Our basic methodological approach implied, therefore, a sampling strategy which focussed on a coverage of different benthic habitats (to document the expected spatial variability in the partitioning pattern) rather than on a complete assessment of all oxygen flux pathways at a single station. The values from the various stations were first categorized according to different benthic habitat types distinguished with regard to pronounced spatial discontinuities in the range of the environmental conditions in the study area. For each habitat type, median values of the various measurements were then assigned for each oxygen flux pathway and eventually combined in a BCOC budget.

Within the overall goal of SEAS - to contribute to an understanding of the pelago-benthic coupling in the northern Barents Sea - our results were also intended 
to provide data for a carbon flux model encompassing both pelagial and benthal (E. M. Nöthig et al. unpubl.).

\section{STUDY AREA}

The northern Barents Sea is a high-latitude continental shelf sea strongly influenced by cold water masses. In general, environmental conditions are high Arctic, i.e. characterized by very low, but relatively constant water temperatures, permanent or persistent ice cover, and large seasonal fluctations in the light regime (Hempel 1985). The current knowledge of the ecologically relevant physical features of the Barents Sea has been reviewed by Loeng (1989).

The bathymetry of the Barents Sea is characterized by several shallow shelf banks, segregated by a complex pattern of rather deep shelf depressions $(>200 \mathrm{~m}$ ). A sharp Polar Front separates relatively warm Atlantic water $\left(T>2^{\circ} \mathrm{C}, \mathrm{S}>35\right)$ in the southern Barents Sea from cold Arctic water $\left(T<0^{\circ} \mathrm{C}, \mathrm{S}<34.8\right)$ in the northern part (Loeng 1989). Arctic-Atlantic Water $\left(-0.5^{\circ} \mathrm{C}\right.$ $<T<2^{\circ} \mathrm{C}, 34.8<\mathrm{S}<35.0$ ) is formed by mixing at the front. The northern Barents Sea is in both the permanent and the seasonal pack ice zones which encircle the central Arctic Ocean. There is, however, a considerable seasonal and also interannual variation in the position of the marginal ice zone (for details see Loeng 1989). River input and sediment load are generally lower in the Barents Sea than in other continental shelf seas of the Eurasian Arctic (Grebmeier and Barry 1991). Seabed characteristics of the northern Barents Sea, however, are only known with low resolution. According to Zenkevitch (1963), most of the area is covered by fine-grained brown sediment with low organic carbon content.

Primary productivity of the Barents Sea as a whole has been reported to range from 60 to $80 \mathrm{~g} \mathrm{C} \mathrm{m}^{-2} \mathrm{yr}^{-1}$, most of which occurs during the spring bloom (Loeng 1989). In the ice-covered region north of Svalbard, however, Stromberg (1989) estimated rates of only about $10 \mathrm{~g} \mathrm{C} \mathrm{m}^{-2} \mathrm{yr}^{-1}$. The bulk of the yearly primary production in the seasonally ice-covered northern Barents Sea is assumed to take place within the marginal ice zone which traverses the area while receding from its winter position at the Polar Front during the period June to August (Grebmeier \& Barry 1991). Pfannkuche \& Thiel (1987) found surprisingly high levels of chlorophyll in sediment samples from the continental shelf and slope northeast of Svalbard, indicating a substantial sedimentation of phytodetritus to the seabed.

In general, both species numbers and standing stock of the benthos are known to be comparatively high in the Barents Sea, presumably due to relatively high pelagic primary production, short food chains, low temperature and, accordingly, low organic matter decomposition as well as long life span of the fauna (Grebmeier \& Barry 1991). For the northern Barents Sea, however, the knowledge on composition, distribution and stock size of benthic communities has not been increased considerably since Zenkevitch (1963). according to whom the fauna is characterized by high Arctic forms, primarily brittle stars like Ophiopleura borealis and Ophiacantha bidentata and the holothurian Molpadia sp. Zenkevitch (1963) described the benthic communities as significantly less diverse than those of the southern Barents Sea. Summarizing Russian quantitative inventories carried out with grabs in the deeper parts of the northern Barents Sea, he reported average biomass to be $30 \mathrm{~g}$ wet wt $\mathrm{m}^{-2}$ at maximum, thus 5 to 10 times less than values found in the richest regions under the Polar Front or west of Novaya Zemlya.

\section{MATERIAL AND METHODS}

Our results are based on samples collected during an expedition by RV 'Polarstern' (ARK VIII/2) in June/ July 1991 to the offshore Barents Sea shelf east of Svalbard (for a detailed cruise report see Rachor 1992). Different approaches were used to assess the respiration of various portions of the benthic communities: the sediment community (which includes endobenthic meio- and small macrofaunal organisms), megabenthic endobenthos, megabenthic epibenthos, and fish.

SCOC. SCOC was estimated by collecting virtually undisturbed sediment cores together with overlying bottom water, using an improved version of the multiple corer (MUC) designed by Barnett et al. (1984). Two or three sediment cores (about $75 \mathrm{~cm}^{2}$ each) were run in parallel on each station. The oxygen concentration in the water above the sediment was measured as a function of incubation time (for details see Hulth et al. 1994). These measurements yielded total sediment oxygen consumption (TSOC) rates, including both the diffusive and biologically mediated transport of oxygen from the overlying bottom water into the sediment. We defined SCOC as a measure of the aerobic mineralization rate of organic carbon in sediments, i.e. SCOC is calculated from TSOC by subtraction of the oxygen used for the oxidation of reduced compounds, such as sulfide, ammonium, iron and manganese, diffusing from below. Except for the amount of oxygen used for nitrification (calculated from sediment-water incubations and acetylene blocking technique), oxidation of other reduced compounds was assumed to be of less importance in the study area (T. H. Blackburn, P. O. J. Hall, S. Hulth \& A. Landén unpubl., Hall, Blackburn, Hulth \& Landén unpubl.). 
Meiobenthos. Meiofauna samples were taken using a $10 \mathrm{~cm}$ diameter core either directly from the MUC or as a subsample from a box core. The meiofauna was largely composed of nematodes and copepods. These were extracted from the sediment by the methods of Warwick (1984) and thereafter these 2 taxa were treated separately. For each site, between 100 and 200 nematodes were measured and their body volume calculated (Warwick \& Price 1979). The length (I) and width ( $w$ ) of 100 harpacticoid copepods from each site was measured and their body volumes $(V)$ calculated using the formula $V=4871 \mathrm{w}^{2}$. The constant 487 was the mean value for samples taken previously in Spitsbergen (J. M. Gee pers, comm.). In both cases, the specific gravity estimate of Feller \& Warwick (1988) permitted the conversion of volume to mass.

Meiofaunal respiration was estimated as the total respiration of both harpacticoid copepods and nematodes using the function given by Grant \& Schwinghamer (1987) which relates the respiration of the total meiofaunal community $\left(R, \mathrm{~mm}^{3} \mathrm{O}_{2} \mathrm{~m}^{-2} \mathrm{~h}^{-1}\right)$ to its total biovolume $\left(V, \mathrm{~mm}^{3} \mathrm{~m}^{-2}\right): R=2.90 \mathrm{~V}^{0.80}$. The respiration figures were converted to $\mu \mathrm{mol} \mathrm{O}_{2} \mathrm{~m}^{-2} \mathrm{~h}^{-1}$ by dividing by 22.4 . Since this relationship has been established for a temperature of $10^{\circ} \mathrm{C}$, the respiration estimates were subsequently standardized to the ambient temperatures at the stations using $Q_{10}=2$.

Macro- and megafaunal endobenthos. The macrobenthic infauna was sampled with a $0.25 \mathrm{~m}^{2}$ box corer, using a $0.1 \mathrm{~m}^{2}$ frame for subsampling, or with a large multibox corer ( 5 to 8 individual cores of $225 \mathrm{~cm}^{2}$ each). The sediment was gently washed through a screen of $0.5 \mathrm{~mm}$ mesh size. The material retained was fixed in 8 to $10 \%$ formalin. In the laboratory all animals were picked out, identified to putative species and weighed (blotted wet mass).

A comparatively small number of species accounted for the bulk of biomass of most samples. For each of these species, the total wet mass was assessed. These values were then used for the calculation of oxygen consumption by employing mean mass-specific respiration rates for each major taxon. These respiration rates were assessed by direct closed-bottle measurements of specimens from various taxa at ambient temperatures on board 'Polarstern' (for details see Opalinski 1992). All specimens measured were megabenthic organisms (collected from trawl catches or core samples) with a wet body mass distinctly greater than $1 \mathrm{~g}$ (K. W. Opalinski unpubl. data). The mass-specific metabolic rates used to estimate the total respiration of the 'smaller macrofaunal' organisms (defined here as specimens with wet body masses of ca 1 to $100 \mathrm{mg}$ ) were raised by a factor of 3 to account for size dependency effects (Gerlach et al. 1985).
For the partitioning within SCOC data, any endobenthic individuals with a wet body mass $>0.5 \mathrm{~g}$ were arbitrarily allocated to the community portion 'endobenthic megafauna'. These animals tend to occur at such low densities that they are undersampled by coring methods. Therefore, they were not included in SCOC measurements. Their chance occurrence would tend to substantially increase the sample biomass and, as a result, the calculation of sample respiration. Nevertheless, a separate assessment of biomass and respiration of these large animals was attempted, and it was accepted that the values obtained are conservative estimates.

Megafaunal epibenthos. The assessment of the respiration of the epibenthic community portion was confined to numerically dominant brittle star species. Even though some of these species had an average wet body mass $<0.5 \mathrm{~g}$, all brittle stars were allocated to the megabenthic size fraction because they were not included in SCOC measurements. Their respiration was assessed by combining density figures with individual respiration rates. For the estimation of abundances, we employed seafloor photography which allowed the identification and counting of brittle star individuals of disc diameters as low as $1 \mathrm{~mm}$ (for details see Piepenburg \& von Juterzenka 1994). For species identification, we referred to specimens collected from trawl catches and/or box corer samples taken nearby. At each station, a sequence of 60 to 70 single pictures, each imaging approximately $1 \mathrm{~m}^{2}$ of seabed, were taken, distributed along a transect of about $300 \mathrm{~m}$ length. For each brittle star species, mean abundance values per station were assessed.

The measurements of individual respiration rates of epibenthic organisms collected from trawl catches or grab samples were carried out at $0^{\circ} \mathrm{C}\left( \pm 0.1^{\circ} \mathrm{C}\right)$ using 2 methods: (1) intermittent-flow respirometry (Steffensen 1989) and (2) closed-bottle couloximetry (Peck \& Uglow 1990). These approaches provided precise values of individual standard metabolism and permitted the consideration of the artificial, stress-induced increase of oxygen consumption in the first phase of each measurement. For details concerning the respiration measurements see von Dorrien (1993) and Schmid (1994).

For each brittle star species, the total population respiration was estimated by multiplying abundance and a mean individual respiration rate. The sizes of the specimens used for the measurement of these rates encompassed the average body size of the respective population. The total oxygen consumption of the epibenthic megafauna was approximated by summation of the oxygen uptake of the 5 brittle star species

Fish. The assessment of the oxygen flow through the benthic fish fauna was based on estimates of total fish 
biomass. Neither abundance nor biomass figures could be obtained from seabed photographs but had to be derived from standardized bottom trawl catches (von Dorrien 1993). Standard metabolic rates of 7 cottid and zoarcid fish species have been measured by using the intermittent flow method (von Dorrien 1993). A functional relationship between wet body mass and individual oxygen consumption rates was established, pooled for all species. For each station, the individual respiration rate of a mean-sized benthic fish was estimated by applying the pooled average fish wet body mass to this function. From these individual standard rates, the mean in situ mass specific rates were calculated by dividing by mean body mass and by multiplying with a factor of 1.5 to account for the increase of oxygen demand by fish under natural conditions. The total fish respiration per station was eventually assessed by multiplying these in situ rates and the total fish biomass.

\section{RESULTS}

Most of the 20 stations considered in our study were distributed along an approximately $400 \mathrm{~km}$ long north-south transect across the northwestern Barents Sea between $80^{\circ} 50^{\prime} \mathrm{N}$ and $78^{\circ} 36^{\prime} \mathrm{N}$ (Fig. 1). Water depths ranged from 80 to $1010 \mathrm{~m}$ (Table 1 ). Thus, the study area encompassed locations at the shallow shelf off Nordaustlandet, Kvitøya, Kong Karls Land and Stor Bank as well as deeper regions (>300 $\mathrm{m}$ ) such as the continental slope to the Nansen Basin and the shelf trenches between Nordaustlandet and Kvitøya (Kvitøyarenna) and Kong Karls Land and Stor Bank. Most stations were covered with sea ice, ranging from $>8 / 10$ cover north of Kvitøya and over the Kong Karls Shelf to drift ice at Kvitoya. Stn 040 at the southern slope of Stor Bank was situated at the sharply pronounced ice edge when samples were taken there at the end of June. The stations at Stor Bank sampled about 1 mo later (Table 1; Stns 136, 138, $141,143)$ were essentially free of ice

\section{Benthic habitat types}

Two physically and, supposedly, ecologically rather homogenous station groups were identified. They differed primarily in terms of their sedimentological signature (Fig. 2a): shallow shelf sites were generally characterized by coarse-grained sediments with low proportions of silt and clay [fines (i.e. sediments $<63 \mu \mathrm{m}$ grain size) $<40 \%$ ], sites in shelf depressions and on the slopes by fine sediments (fines $>50 \%$ ). Furthermore, seabed imaging revealed that in shallow areas large stones and boulders locally occurred in significant quantities but were seldom found at deeper locations (Piepenburg unpubl. data). There was only a slight overlap between station groups with respect to water depth (80 to $240 \mathrm{~m}$ and 190 to $1010 \mathrm{~m}$, respectively) and organic carbon content $(0.35$ to $0.81 \%$ and 0.73 to $1.57 \%$, respectively). However, hydrography was of minor importance for the discrimination of site groups (Fig. 2b): only the shallowest of the shelf stations $(\leq 100 \mathrm{~m})$ were characterized by very cold Arctic Water, whereas both the deeper shelf bank sites and the stations on the slopes were characterized by warmer, more saline water.

Unfortunately, there were no data available on hydrography and/or sediment properties for some stations. These had to be allocated to a station group 
Table 1. Station parameters; Cruise ARK VIII/2 (EPOS II) of RV 'Polarstern' in June/July 1991. See text for definition of 'shallow' and 'deep' stations. BT bottom water temperature; Fines: silt and clay; TOC: total organic carbon. Data types: SCOC, sediment community oxygen consumption; Meio, meiobenthos; Endo, both macro- and megafanual endobenthos; Epi, megafaunal epibenthos; Fish, fish. BT and salinity data provided by U. Schauer, fines and TOC data provided by H. Grobe. -: no data

\begin{tabular}{|c|c|c|c|c|c|c|c|c|c|c|c|c|c|c|}
\hline Stn & $\begin{array}{c}\text { Date } \\
\text { (1991) }\end{array}$ & $\begin{array}{l}\text { Lat. } \\
\text { (N) }\end{array}$ & $\begin{array}{l}\text { Long. } \\
\text { (E) }\end{array}$ & Topography & $\begin{array}{l}\text { Depth } \\
\text { (m) }\end{array}$ & $\begin{array}{l}\mathrm{BT} \\
\left({ }^{\circ} \mathrm{C}\right)\end{array}$ & Salinity & $\begin{array}{l}\text { Fines } \\
(\% \mathrm{dw})\end{array}$ & $\begin{array}{c}\text { TOC } \\
(\% d w)\end{array}$ & scod & $\begin{array}{l}\text { ata av } \\
\text { Meio }\end{array}$ & $\begin{array}{l}\text { vailable } \\
\text { Endo }\end{array}$ & $\begin{array}{l}\text { le for: } \\
\text { Epi }\end{array}$ & Fish \\
\hline \multicolumn{15}{|c|}{ Shallow } \\
\hline 102 & 13 Jul & $80^{\circ} 58^{\prime}$ & $27^{\circ} 14^{\prime}$ & Nordaustlandet Shelf & 100 & -1.52 & 34.73 & 20.3 & 0.35 & - & - & - & $\mathrm{x}$ & - \\
\hline 104 & 14 Jul & $81^{\circ} 27^{\prime}$ & $31^{\circ} 39^{\prime}$ & Kvitøya Shelf & 240 & 1.49 & 34.91 & 28.8 & 0.63 & - & $\mathrm{x}$ & $\mathrm{x}$ & - & $\mathrm{x}$ \\
\hline 116 & $20 \mathrm{Jul}$ & $80^{\circ} 50^{\prime}$ & $30^{\circ} 39^{\prime}$ & Kvitøya Shelf & 100 & -0.42 & 34.46 & 16.1 & 0.43 & - & - & - & $\mathrm{x}$ & - \\
\hline 121 & $21 \mathrm{Jul}$ & $80^{\circ} 43^{\prime}$ & $28^{\circ} 32^{\prime}$ & Nordaustlandet Shelf & 150 & - & - & - & - & - & - & - & $\mathrm{x}$ & - \\
\hline 132 & 24 Jul & $79^{\circ} 11^{\prime}$ & $31^{\circ} 44^{\prime}$ & Kong Karls Shelf & 80 & -1.48 & 34.17 & 25.8 & 0.48 & - & $\mathrm{x}$ & $\mathrm{x}$ & $\mathrm{x}$ & - \\
\hline 136 & $25 \mathrm{Jul}$ & $77^{\circ} 59^{\prime}$ & $32^{\circ} 58^{\prime}$ & Stor Bank & 140 & 0.64 & 34.75 & 39.1 & 0.81 & - & $\mathrm{x}$ & $\mathrm{x}$ & - & $\mathrm{x}$ \\
\hline 138 & 25 Jul & $77^{\circ} 27^{\prime}$ & $33^{\circ} 01^{\prime}$ & Stor Bank & 160 & 1.62 & 34.95 & - & - & - & - & - & $x$ & - \\
\hline 141 & $26 \mathrm{Jul}$ & $76^{\circ} 57^{\prime}$ & $33^{\circ} 20^{\prime}$ & Stor Bank & 150 & 1.73 & 34.93 & - & - & - & - & - & - & $\mathrm{x}$ \\
\hline \multicolumn{15}{|c|}{ Deep } \\
\hline 040 & $23 \mathrm{Jun}$ & $76^{\circ} 37^{\prime}$ & $34^{\circ} 51^{\prime}$ & Stor Bank Slope & 220 & 1.40 & 34.97 & 83.2 & 1.45 & $x$ & - & - & - & - \\
\hline 101 & $12 \mathrm{Jul}$ & $81^{\circ} 18^{\prime}$ & $18^{\circ} 38^{\prime}$ & Nansen Basin Slope & 550 & 1.71 & 34.96 & 85.9 & 1.57 & $\mathrm{x}$ & - & - & - & - \\
\hline 105 & 15 Jul & $81^{\circ} 25^{\prime}$ & $30^{\circ} 45^{\prime}$ & Nansen Basin Slopo & 400 & 1.47 & 34.91 & 55.1 & 0.73 & $\mathrm{x}$ & - & - & - & $x$ \\
\hline 107 & $16 \mathrm{Jul}$ & $81^{\circ} 25^{\prime}$ & $30^{\circ} 40^{\prime}$ & Nansen Basin Slope & 310 & 1.62 & 34.92 & - & - & - & - & - & - & $\mathrm{x}$ \\
\hline 112 & $19 \mathrm{Jul}$ & $81^{\circ} 34^{\prime}$ & $31^{\circ} 10^{\prime}$ & Nansen Basin Slope & 1010 & -0.24 & 34.90 & 87.3 & 1.08 & $\mathrm{x}$ & - & - & - & - \\
\hline 117 & $20 \mathrm{Jul}$ & $80^{\circ} 50^{\prime}$ & $30^{\circ} 06^{\prime}$ & Kvitøyarenna Slope & 200 & 0.18 & 34.72 & 76.7 & 0.89 & - & $x$ & $\mathrm{x}$ & $x$ & - \\
\hline 119 & $20 \mathrm{Jul}$ & $80^{\circ} 44^{\prime}$ & $29^{\circ} 30^{\prime}$ & Kvitøyarenna & 510 & 0.24 & 34.83 & 93.1 & 1.36 & $\mathrm{x}$ & - & $\mathrm{x}$ & - & $\mathrm{x}$ \\
\hline 124 & $22 . \mathrm{Iul}$ & $80^{\circ} 21^{\prime}$ & $29^{\circ} 08^{\prime}$ & Kvitayarenna & 360 & 0.29 & 34.82 & 59.2 & 0.80 & - & - & $x$ & $x$ & - \\
\hline 130 & $24 \mathrm{Jul}$ & $79^{\circ} 28^{\prime}$ & $30^{\circ} 31^{\prime}$ & Kvitoya Slope & 230 & 2.09 & 34.79 & - & - & - & - & - & $\mathrm{x}$ & - \\
\hline 131 & $24 \mathrm{Jul}$ & $79^{\circ} 27^{\prime}$ & $30^{\circ} 30^{\prime}$ & Kvitøya Slope & 330 & 1.75 & 34.88 & - & - & - & - & - & $\mathrm{x}$ & - \\
\hline 134 & $24 \mathrm{JuI}$ & $78^{\circ} 40^{\prime}$ & $32^{\circ} 09^{\prime}$ & Kong Karls Renna & 280 & 1.62 & 34.90 & 94.1 & 1.26 & $\mathrm{x}$ & - & - & - & $\mathrm{x}$ \\
\hline 143 & $27 \mathrm{Jul}$ & $76^{\circ} 36^{\prime}$ & $34^{\circ} 49^{\prime}$ & Stor Bank Slope & 190 & 1.24 & 34.98 & 86.3 & 1.42 & $\mathrm{x}$ & $\mathrm{x}$ & $\mathrm{x}$ & - & - \\
\hline
\end{tabular}
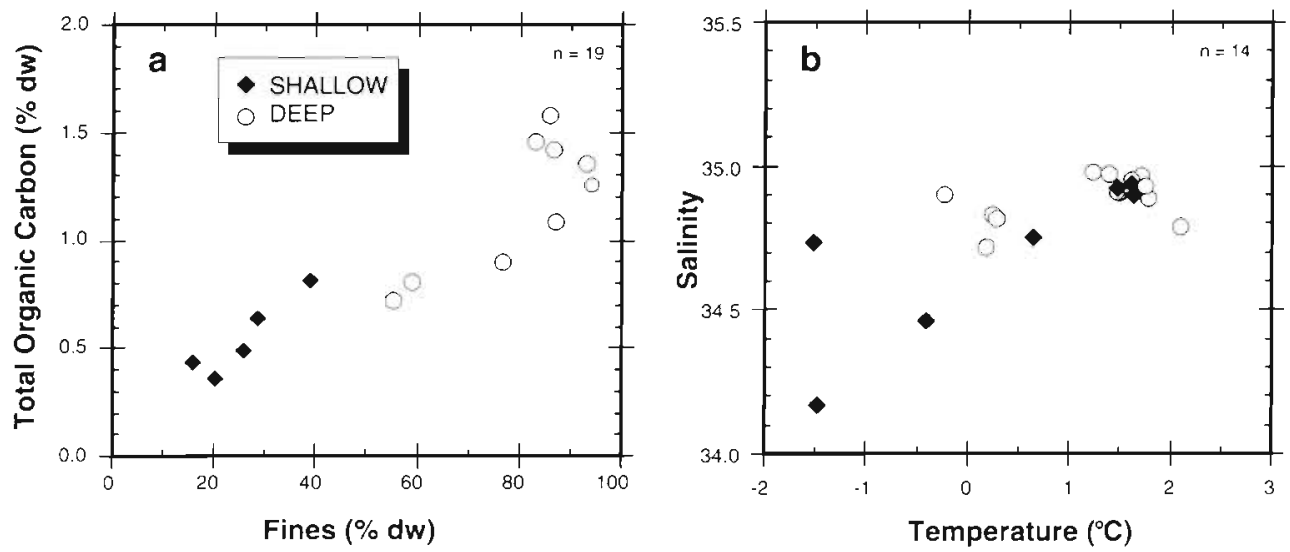

Fig. 2. Hydrographical and sedimentological station parameters. (a) Sediment surfaces: total organic carbon (\% dry wt) vs percentage of silt and clay (fines \% dry wt); data provided by $\mathrm{H}$. Grobe. (b) Bottom water: temperature vs salinity; data provided by U. Schauer See text for definition of 'shallow' and 'deep' stations

according to their water depth. Therefore, and because water depth was, next to sediment grain size, the most distinctive factor, the 2 distinguished station groups were termed 'shallow' and 'deep'.

\section{$\mathrm{SCOC}$}

At 7 stations, SCOC values were estimated from measured rates of TSOC. All of these stations were situated in the 'deep' area, because the MUC could not be employed at stations with coarse-grained and stony seabeds. TSOC measurements ranged from 77 to $179 \mu \mathrm{mol} \mathrm{O}_{2} \mathrm{~m}^{-2} \mathrm{~h}^{-1}$ and the oxygen flows due to nitrification from not detectable rates at Stn 119 to $21 \mu \mathrm{mol}$ $\mathrm{O}_{2} \mathrm{~m}^{-2} \mathrm{~h}^{-1}$ at $\mathrm{Stn} 040$, i.e they generally accounted for only minor proportions (12\% at maximum) of TSOC. The calculated values of SCOC ranged from 72 to $158 \mu \mathrm{mol} \mathrm{O} \mathrm{O}^{-2} \mathrm{~h}^{-1}$, being lowest at the continental slope of the Nansen Basin and highest on the southern slope of the Stor Bank. SCOC was significantly correlated with water depth (Fig. $3 ; r^{2}=0.892, p=0.001$ ), 


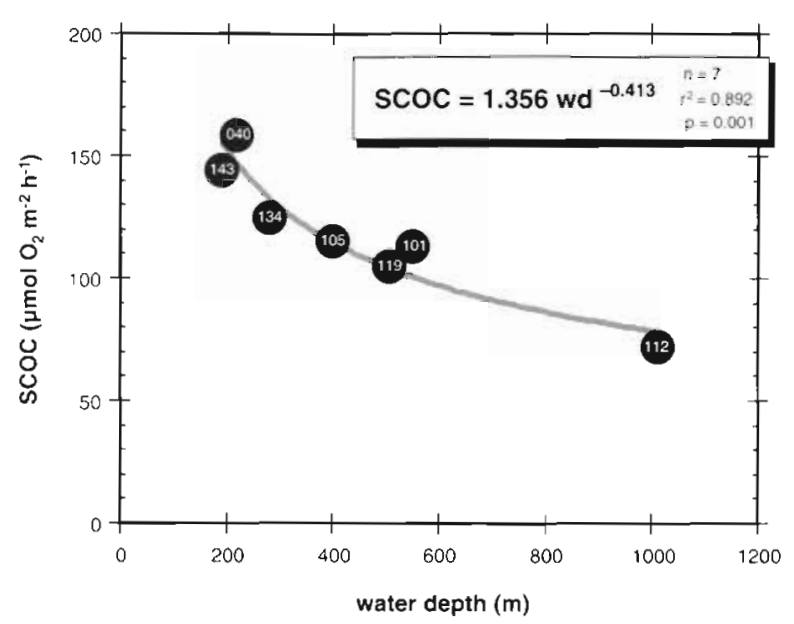

Fig. 3. Sediment community oxygen consumption (SCOC) as a function of water depth (data from Hulth et al. 1994)

Table 2. Mean biomass and total respiration of meiobenthic nematodes and harpacticoid copepods in the northern Barents Sea in June/July 1991 See text for definition of 'shallow' and 'deep' stations. Cop. wt.: wet weight of harpacticoid copepods $\left(\mathrm{g} \mathrm{m}^{-2}\right)$; Nem. wt: wet weight of nematodes $\left(\mathrm{g} \mathrm{m}^{-2}\right)$; Meio. wt: wet weight of harpacticoid copepods and nematodes $\left(\mathrm{g} \mathrm{m}^{-2}\right)$; Meio. vol.. biovolume of harpacticoid copepods and nematodes $\left(\mathrm{mm}^{3} \mathrm{~m}^{-2}\right) ; R_{r-10}$ total respiration of harpacticoid copepods and nematodes, estimated for a temperature of $10^{\circ} \mathrm{C}\left(\mu \mathrm{mol} \mathrm{O} \mathrm{O}^{-2} \mathrm{~h}^{-1}\right)$ : $\mathrm{R}_{a n \text { stu }}$ : total respiration of harpacticoid copepods and nematodes, standardized to lower in situ temperatures ( $\mu \mathrm{mol} \mathrm{O} \mathrm{O}_{2} \mathrm{~m}^{-2} \mathrm{~h}^{-1}$ )

\begin{tabular}{|lrrrrrr|}
\hline Sin & Cop.wt & Nem. wt & Meio.wt & Meio.vol. & $\mathrm{R}_{\mathrm{T}=10}$ & $\mathrm{R}_{\text {in situ }}$ \\
\hline Shallow & & & & & & \\
104 & 0.01 & 0.11 & 0.12 & 101.6 & 5.2 & 2.9 \\
132 & 0.12 & 0.22 & 0.34 & 297.9 & 12.4 & 5.6 \\
136 & 0.15 & 1.76 & 1.90 & 1683.9 & 49.4 & 25.8 \\
Deep & & & & & & \\
117 & 0.18 & 0.56 & 0.74 & 656.0 & 23.2 & 11.8 \\
143 & 0.09 & 0.14 & 0.23 & 207.7 & 9.3 & 5.0 \\
\hline
\end{tabular}

indicating that no site was located in a 'depocenter' (sensu Walsh 1988) characterized by an extraordinarily enhanced benthic oxygen uptake. No significant correlations, however, were found between SCOC and temperature $\left(r^{2}=0.406, p=0.124\right)$, total organic carbon (TOC) in the surficial sediment $\left(r^{2}=0.177, p=0.347\right)$, or grain size (percentage of fines; $r^{2}=0.000, p=0.990$ ). A multiple regression of SCOC on depth, temperature, TOC, and fines was also not significant (adjusted multiple $r^{2}=0.564, p=0.270$ ).

\section{Meiobenthos}

Total biomass of nematodes was 3- to 10-fold larger than that of copepods (Table 2). Total meiofaunal respiration ranged from 2.9 to $25.8 \mu \mathrm{mol} \mathrm{O} \mathrm{O}^{-2} \mathrm{~h}^{-1}$. There was no significant difference between station groups in either meiofaunal biomass, share of copepods or total meiofaunal oxygen uptake (U-tests, $\mathrm{p} \geq 0.05$ ).

\section{Macrofaunal endobenthos}

Polychaetes, notably maldanids, dominated the macrofaunal endobenthos, both in terms of mean abundance and mean wet biomass. at most stations (Table 3; more details in M. A. Kendall unpubl.). At Stns 119, 124 and 136 a few juvenile echinoderms (Ctenodiscus crispatus) made up much of the biomass, and at Stn 132 small bivalve molluscs (Nuculana pernula, Dacrydium vitreum) were dominant. Generally, a few species accounted for most of the total wet biomass and total respiration of the macrobenthic infauna, which ranged

Table 3. Mean wet biomass ( $\mathrm{g} \mathrm{m}^{-2}$ ) and total respiration ( $\mathrm{\mu mol} \mathrm{O}_{2} \mathrm{~m}^{-2} \mathrm{~h}^{-1}$ ) of small endobenthic macrofauna (wet body mass $\leq 0.5 \mathrm{~g})$ in the northern Barents Sea in June/July 1991. See text for definition of shallow and deep stations. Respiration estimated from biomass using taxon- and mass-specific metabolic rates (MR, $\mu \mathrm{mol} \mathrm{O}_{2} \mathrm{~g}^{-1} \mathrm{~h}^{-1}$ )

\begin{tabular}{|c|c|c|c|c|c|c|c|c|c|c|c|c|}
\hline \multirow[t]{2}{*}{ Stn } & \multicolumn{2}{|c|}{$\begin{array}{l}\text { Polychaetes } \\
(M R=0.6)\end{array}$} & \multicolumn{2}{|c|}{$\begin{array}{c}\text { Molluscs } \\
(\mathrm{MR}=0.15)\end{array}$} & \multicolumn{2}{|c|}{$\begin{array}{l}\text { Crustaceans } \\
(\mathrm{MR}=3)\end{array}$} & \multicolumn{2}{|c|}{$\begin{array}{l}\text { Echinoderms } \\
\qquad(\mathrm{MR}=1)\end{array}$} & \multicolumn{2}{|c|}{$\begin{array}{l}\text { Others } \\
(\mathrm{MR}=1)\end{array}$} & \multicolumn{2}{|c|}{ Total } \\
\hline & Biom. & Resp. & Biom. & Resp. & Biom. & Resp. & Biom. & Resp. & Biom. & Resp. & Biom. & Resp. \\
\hline \multicolumn{13}{|c|}{ Shallow } \\
\hline 104 & 9.2 & 5.5 & 0.3 & $<0.1$ & 0.3 & 0.9 & 1.8 & 1.8 & 0.9 & 0.9 & 12.5 & 9.2 \\
\hline 132 & 16.7 & 10.0 & 80.7 & 12.1 & 4.0 & 12.0 & 2.4 & 2.4 & 0.2 & 0.2 & 104.0 & 36.7 \\
\hline 136 & 4.5 & 2.7 & 0.3 & $<0.1$ & 0.4 & 1.3 & 10.2 & 10.2 & 0.4 & 0.4 & 15.7 & 14.6 \\
\hline \multicolumn{13}{|c|}{ Deep } \\
\hline 117 & 45.9 & 27.6 & 14.5 & 2.2 & 0.4 & 1.3 & 0 & 0 & 3.2 & 3.2 & 64.0 & 34.2 \\
\hline 119 & 18.5 & 11.1 & 6.3 & 1.0 & 0.1 & 0.3 & 8.3 & 8.3 & 1.8 & 1.8 & 35.0 & 22.5 \\
\hline 124 & 73.4 & 44.0 & 1.5 & 0.2 & 0.7 & 2.1 & 11.1 & 11.1 & 2.5 & 2.5 & 89.2 & 60.0 \\
\hline 143 & 12.2 & 7.3 & 0.4 & $<0.1$ & 0.3 & 0.9 & 0 & 0 & 0.1 & 0.1 & 13.0 & 8.4 \\
\hline
\end{tabular}


Table 4. Mean wet biomass $\left(\mathrm{g} \mathrm{m}^{-2}\right)$ and total respiration $\left(\mu \mathrm{mol} \mathrm{O}_{2} \mathrm{~m}^{-2} \mathrm{~h}^{-1}\right)$ of endobenthic megafauna (wet body mass $\left.>0.5 \mathrm{~g}\right)$ in the northern Barents Sea in June/July 1991 See text for definition of 'shallow' and 'deep' stations. Respiration estimated from biomass using taxon- and mass-specific metabolic rates ( $\mathrm{MR}, \mu \mathrm{mol} \mathrm{O} \mathrm{O}^{-1} \mathrm{~h}^{-1}$ )

\begin{tabular}{|c|c|c|c|c|c|c|c|c|c|c|c|c|}
\hline \multirow[t]{2}{*}{ Stn } & \multicolumn{2}{|c|}{$\begin{array}{c}\text { Polychaetes } \\
(\mathrm{MR}=0.2)\end{array}$} & \multicolumn{2}{|c|}{$\begin{array}{c}\text { Molluscs } \\
(\mathrm{MR}=0.05)\end{array}$} & \multicolumn{2}{|c|}{$\begin{array}{c}\text { Crustaceans } \\
(\mathrm{MR}=1.1)\end{array}$} & \multicolumn{2}{|c|}{$\begin{array}{c}\text { Echinoderms } \\
(\mathrm{MR}=0.3)\end{array}$} & \multicolumn{2}{|c|}{$\begin{array}{c}\text { Others } \\
(\mathrm{MR}=0.3)\end{array}$} & \multicolumn{2}{|c|}{ Total } \\
\hline & Biom. & Resp. & Biom. & Resp. & Biom. & Resp & Biom. & Resp. & Biom. & Resp. & Biom & Resp. \\
\hline \multicolumn{13}{|c|}{ Shallow } \\
\hline 104 & 0 & 0 & 0 & 0 & 0 & 0 & 0 & 0 & 0 & 0 & 0 & 0 \\
\hline 132 & 0 & 0 & 77.0 & 3.9 & 0 & 0 & 0 & 0 & 22.2 & 6.7 & 99.2 & 10.5 \\
\hline 136 & 18.2 & 3.6 & 0 & 0 & 0 & 0 & 0 & 0 & 0 & 0 & 18.2 & 3.6 \\
\hline \multicolumn{13}{|c|}{ Deep } \\
\hline 117 & 0 & 0 & 0 & 0 & 0 & 0 & 8.5 & 2.5 & 0 & & 8.5 & 2.5 \\
\hline 119 & 0 & 0 & 0 & 0 & 0 & 0 & 121.4 & 36.4 & 0 & 0 & 121.4 & 36.4 \\
\hline 124 & 90.2 & 18.0 & 0 & 0 & 0 & 0 & 40.8 & 12.2 & 0 & 0 & 131.0 & 30.3 \\
\hline 143 & 0 & 0 & 0 & 0 & 0 & 0 & 0 & 0 & 0 & 0 & 0 & 0 \\
\hline
\end{tabular}

from 12.5 to $104.0 \mathrm{~g} \mathrm{~m}^{-2}$ and 8.4 to $60.0 \mu \mathrm{mol} \mathrm{O}_{2} \mathrm{~m}^{-2}$ $\mathrm{h}^{-1}$, respectively (Table 3 ). Respiration values tended to be higher at deep stations, but this difference was not significant ( $U$-test, $\mathrm{p}=0.724$ ).

\section{Megafaunal endobenthos}

Nephtid polychaetes, the bivalves Mya truncata and Hiatella arctica, and the sea star Ctenodiscus crispatus were dominant elements of the megafaunal endobenthos in the cores investigated. The total respiration of this community compartment ranged from 3.6 to $36.4 \mu \mathrm{mol} \mathrm{O} \mathrm{m}^{-2} \mathrm{~h}^{-1}$ (Table 4). As for the macrofaunal respiration, values tended to be higher at 'deep' stations, but again the difference was not significant (U-test, $\mathrm{p}=0.593$ ).

\section{Megafaunal epibenthos}

Densities and individual metabolic rates were determined for 5 brittle star species (Table 5). Ophiocten sericeum was by far the most abundant species on the shallow banks. On the shelf near Kong Karls Land (Stn 132), this species occurred with an extremely high (within-station) mean abundance of about 700 ind. $\mathrm{m}^{-2}$. However, it was almost absent at deeper stations, both on the shelf $(>100 \mathrm{~m})$ and at the slopes $(>200 \mathrm{~m})$. There, epifaunal abundances were generally lower, and Ophiacantha bidentata predominated. This brittle star, as well as Ophiopholis aculeata and Ophiura sarsi, occurred at each station, but the latter 2 species with relatively low abundances. The large-growing Ophioscolex glacialis was absent or comparatively rare in both habitat types. Schmid (1994) reported the size dis-

Table 5. Mean abundance (ind. $\mathrm{m}^{-2}$ ) and total respiration ( $\mu \mathrm{mol} \mathrm{O}_{2} \mathrm{~m}^{-1} \mathrm{~h}^{-1}$ ) of 5 abundant megabenthic brittle star species in the northern Barents Sea in June/July 1991 See text for definition of 'shallow' and 'deep' stations. RR: average individual respiration rates of median-sized specimens ( $\mu \mathrm{mol} \mathrm{O} \mathrm{O}_{2}$ ind. $\left.{ }^{-1} \mathrm{~h}^{-1}\right)$

\begin{tabular}{|c|c|c|c|c|c|c|c|c|c|c|c|c|}
\hline \multirow[t]{2}{*}{ Stn } & \multicolumn{2}{|c|}{$\begin{array}{c}\text { Ophiocten } \\
\text { sericeum } \\
(\mathrm{RR}=0.3)\end{array}$} & \multicolumn{2}{|c|}{$\begin{array}{c}\text { Ophiacantha } \\
\text { bidentata } \\
(\mathrm{RR}=0.3)\end{array}$} & \multicolumn{2}{|c|}{$\begin{array}{c}\text { Ophiopholis } \\
\text { aculeata } \\
(\mathrm{RR}=0.6)\end{array}$} & \multicolumn{2}{|c|}{$\begin{array}{c}\text { Ophiura } \\
\text { sarsi } \\
(\mathrm{RR}=0.6)\end{array}$} & \multicolumn{2}{|c|}{$\begin{array}{c}\text { Ophioscolex } \\
\text { glacialis } \\
(\mathrm{R} R=3)\end{array}$} & \multicolumn{2}{|c|}{ Totals } \\
\hline & Abund. & Resp. & Abund & Resp. & Abund & Resp. & Abund & Resp. & Abund. & Resp. & Abund. & Resp. \\
\hline \multicolumn{13}{|c|}{ Shallow } \\
\hline 102 & 91.8 & 27.6 & 0.2 & 0.1 & 3.8 & 2.3 & 2.0 & 1.1 & 0 & 0 & 97.8 & 31.1 \\
\hline 116 & 40.9 & 12.3 & 2.5 & 0.8 & 4.0 & 2.4 & 0.3 & 0.2 & 0 & 0 & 47.7 & 15.6 \\
\hline 121 & 0 & 0 & 31.5 & 9.5 & 4.0 & 2.4 & 6.9 & 4.1 & 0.2 & 0.5 & 42.5 & 16.4 \\
\hline 132 & 686.6 & 206.0 & 5.0 & 1.5 & 2.1 & 1.3 & $<0.1$ & $<0.1$ & 0 & 0 & 693.8 & 208.8 \\
\hline 138 & 0 & 0 & 48.2 & 14.5 & 0.2 & 0.1 & $<0.1$ & $<0.1$ & 1.4 & 4.3 & 49.8 & 18.9 \\
\hline \multicolumn{13}{|c|}{ Deep } \\
\hline 117 & $<0.1$ & $<0.1$ & 2.8 & 0.8 & 0.6 & 0.4 & $<0.1$ & $<0.1$ & 0.1 & 0.3 & 3.5 & 1.6 \\
\hline 124 & 0 & 0 & 0.7 & 0.2 & 0.7 & 0.4 & 1.6 & 0.9 & 0 & 0 & 2.9 & 1.6 \\
\hline 130 & 0.1 & $<0.1$ & 12.7 & 3.8 & 0.3 & 0.2 & $<0.1$ & $<0.1$ & 0.5 & 1.5 & 13.7 & 5.6 \\
\hline 131 & 0 & 0 & 20.0 & 6.0 & 0.1 & 0.1 & $<0.1$ & $<0.1$ & 0.1 & 0.4 & 20.3 & 6.5 \\
\hline
\end{tabular}


tributions of the brittle star populations studied: the median disc diameters were $6,8,15,16$ and $30 \mathrm{~mm}$ for O. sericeum, $O$. bidentata, $O$. sarsi, $O$. aculeata and $O$. glacialis, respectively; the corresponding median wet body mass values were $0.1,0.2,0.8,2.0$ and about $6.5 \mathrm{~g}$, respectively.

Mean individual oxygen uptake rates of mediumsized specimens of the 5 species (derived from mean routine metabolic rates, raised by $20 \%$ to account for the oxygen demand of the in situ activity metabolism) were correlated with body sizes and ranged from $0.3 \mu \mathrm{mol} \mathrm{O} \mathrm{O}_{2}$ ind $^{-1} \mathrm{~h}^{-1}$ for the small species Ophiocten sericeum and Ophiacantha bidentata to $3 \mu \mathrm{mol} \mathrm{O}_{2}$ ind..$^{-1} \mathrm{~h}^{-1}$ for the large Ophioscolex glacialis (see Table 5). Corresponding to the abundances, the total epifaunal oxygen uptake rates were significantly higher on the banks than at the deeper stations (U-test, $\mathrm{p}=$ 0.013 ), ranging from 15.6 to $208.8 \mu \mathrm{mol} \mathrm{O} \mathrm{m}^{-2} \mathrm{~h}^{-1}$ and from 1.6 to $6.5 \mu \mathrm{mol} \mathrm{O} \mathrm{m}^{-2} \mathrm{~h}^{-1}$, respectively (Table 5).

\section{Fish}

The benthic fish fauna of the study area was primarily composed of species of the families Scorpaenidae, Cottidae, Zoarcidae and Pleuronectidae (Chernova et al. 1992). Total fish abundance and wet biomass, as derived from standardized trawl catches, were low (Table 6). Individual standard oxygen consumption rates were measured for 53 specimens from 7 cottid and zoarcid species, with wet body masses (M) and standard individual respiration rates (SR) between 0.7 and $377 \mathrm{~g}$ and 0.3 and $371.9 \mu \mathrm{mol} \mathrm{O}_{2}$ ind $^{-1} \mathrm{~h}^{-1}$, respectively (von Dorrien 1993). Using a power function fitted

Table 6. Total abundance, total wet biomass, average wet body mass and respiration rates of benthic fish in the northern Barents Sea in June/July 1991. See text for definition of 'shallow' and 'deep' stations. $\mathrm{SVO}_{2}$ : standard respiration rates of average-sized benthic fish individuals $\left(\mu \mathrm{mol} \mathrm{O}_{2} \mathrm{~h}^{-1}\right)$; $\mathrm{IVO}_{2}$ : body mass specific in situ respiration rates of averagesized benthic fish ( $\left.\mu \mathrm{mol} \mathrm{O}_{2} \mathrm{~g}^{-1} \mathrm{~h}^{-1}\right)$; Total resp.: total fish respiration $\left(\mu \mathrm{mol} \mathrm{O} \mathrm{O}_{2} \mathrm{~m}^{-2} \mathrm{~h}^{-1}\right)$

\begin{tabular}{|lrrrrrr|}
\hline Stn & $\begin{array}{c}\text { Abund. } \\
\left.\text { (ind. } \mathrm{m}^{-2}\right)\end{array}$ & $\begin{array}{c}\text { Biom. } \\
\left(\mathrm{g} \mathrm{m}^{-2}\right)\end{array}$ & $\begin{array}{c}\text { Body } \\
\text { mass }(\mathrm{g})\end{array}$ & $\mathrm{SVO}_{2}$ & $\mathrm{IVO}_{2}$ & $\begin{array}{r}\text { Total } \\
\text { resp. }\end{array}$ \\
\hline Shallow & & & & & & \\
104 & 0.01 & 0.06 & 5.1 & 2.7 & 0.8 & $<0.1$ \\
136 & 0.04 & 0.14 & 4.0 & 2.2 & 0.8 & 0.1 \\
141 & 0.04 & 0.14 & 3.7 & 2.0 & 0.8 & 0.1 \\
Deep & & & & & & \\
105 & 0.01 & 0.07 & 4.5 & 2.4 & 0.8 & $<0.1$ \\
107 & 0.03 & 1.24 & 41.9 & 20.0 & 0.7 & 0.9 \\
119 & 0.01 & 0.62 & 44.9 & 21.4 & 0.7 & 0.4 \\
134 & 0.04 & 0.37 & 9.0 & 4.6 & 0.8 & 0.3 \\
\hline
\end{tabular}

to the pooled values of all species ( $\mathrm{SR}=0.018 \mathrm{M}^{0.95}, \mathrm{n}=$ $53, \mathrm{r}^{2}=0.82$ ), the average individual standard respiration rates (mean $\mathrm{SVO}_{2}$ ) and mass specific in situ respiration rates (mean $\mathrm{IVO}_{2}$ ) of average-sized benthic were estimated for each station (Table 6). The total fish respiration rates were generally very low. They ranged from <0.1 to $0.9 \mu \mathrm{mol} \mathrm{O}_{2} \mathrm{~m}^{-2} \mathrm{~h}^{-1}$ (Table 6), being a little higher at the deep stations, but not significantly (U-test, $\mathrm{p}=0.208$ ).

\section{Respiration partitioning}

Except for SCOC, which was not measured on the shallow banks, at least 2 estimates were obtained for each potential benthic oxygen sink in both station groups (Table 7 ). It is evident that the partitioning of the total benthic oxygen flux among the various community compartments differed distinctly between the 2 habitat types.

Table 7 Total respiration ( $\mu \mathrm{mol} \mathrm{O}_{2} \mathrm{~m}^{-2} \mathrm{~h}^{-1}$ ) of benthic community compartments in the northern Barents Sea in June/July 1991 See text for definition of shallow and deep stations. SCOC: sediment community oxygen consumption, (values in parentheses estimated from meio- and macrofaunal respiration; see text); Meio: meiobenthos; Macro: macrofaunal endobenthos; Endo: megafaunal endobenthos; Epi: megafaunal epibenthos; Fish: fish fauna; BCOC: total benthic community oxygen consumption $(=\mathrm{SCOC}+$ Endo + Epi + Fish $)$ -: no data

\begin{tabular}{|c|c|c|c|c|c|c|c|}
\hline \multirow[t]{2}{*}{ Stn } & \multirow{2}{*}{ Total } & \multicolumn{2}{|c|}{ SCOC } & \multicolumn{3}{|c|}{ Megafauna } & \multirow[t]{2}{*}{$\mathrm{BCOC}$} \\
\hline & & Meio & Macro & Endo & Epi & Fish & \\
\hline \multicolumn{8}{|l|}{ Shallow } \\
\hline 102 & - & - & - & - & 31 & - & \\
\hline 104 & - & 3 & 9 & 0 & - & $<0.1$ & \\
\hline 116 & - & - & - & - & 16 & - & \\
\hline 121 & - & - & - & - & 16 & - & \\
\hline 132 & - & 6 & 37 & 11 & 209 & - & \\
\hline 136 & - & 26 & 15 & 4 & - & 0.1 & \\
\hline 138 & - & - & - & - & 19 & - & \\
\hline 141 & - & - & - & - & - & 0.1 & \\
\hline Median & $(66)$ & 6 & 15 & 4 & 19 & 0.1 & (89) \\
\hline \multicolumn{8}{|l|}{ Deep } \\
\hline 040 & 158 & - & - & - & - & - & \\
\hline 101 & 113 & - & - & - & - & - & \\
\hline 105 & 115 & - & - & - & - & $<0.1$ & \\
\hline 107 & - & - & - & - & - & 0.9 & \\
\hline 112 & 72 & - & - & - & - & - & \\
\hline 117 & - & 12 & 34 & 3 & 2 & - & \\
\hline 119 & 105 & - & 22 & 36 & - & 0.4 & \\
\hline 124 & - & - & 60 & 30 & 2 & - & \\
\hline 130 & - & - & - & - & 6 & - & \\
\hline 131 & - & - & - & - & 6 & - & \\
\hline 134 & 125 & - & - & - & - & 0.3 & \\
\hline 143 & 163 & 5 & 8 & 0 & - & - & \\
\hline Median & 115 & 9 & 28 & 17 & 4 & 0.3 & 136 \\
\hline
\end{tabular}



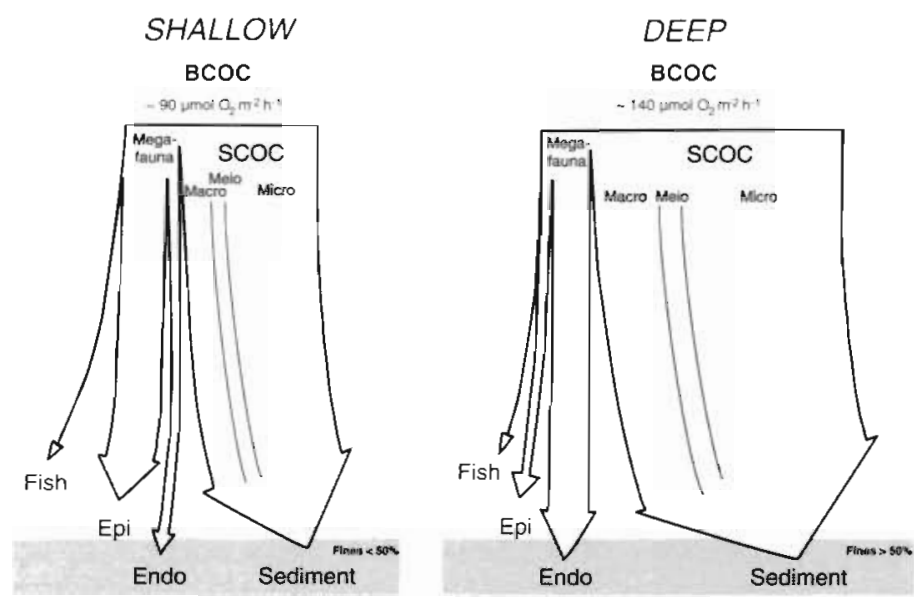

Fig. 4. Benthic community respiration partitioning patterns. Arrow widths represent proportions of median respiration by each benthic community compartment. BCOC: total benthic community oxygen consumption; SCOC: sediment community oxygen consumption; Micro: microbenthos (bacteria, protozoans); Meio: meiobenthos; Macro: small macrobenthic organisms included in sediment cores used for SCOC measurements; Endo: megabenthic endofaunal organisms; Epi: megabenthic epifaunal organisms; Fish: fish

In benthic habitats with fine-grained sediments, usually found at locations in depths $>200 \mathrm{~m}$ with apparently low bottom current velocities, SCOC was the most important pathway of the benthic oxygen flux (median: $115 \mu \mathrm{mol} \mathrm{O}_{2} \mathrm{~m}^{-2} \mathrm{~h}^{-1}$ ). On average, it exceeded the megafaunal respiration by a factor of 5.5 (Fig. 4). The endobenthic macrofauna was estimated to contribute roughly $25 \%$ (median: $28 \mu \mathrm{mol} \mathrm{O} \mathrm{m}^{-2} \mathrm{~h}^{-1}$ ) and meiofauna less than $10 \%$ (median: $9 \mu \mathrm{mol} \mathrm{O} \mathrm{O}^{-2}$ $\mathrm{h}^{-\mathrm{t}}$ ) of the SCOC. This finding implies that the oxygen uptake of the microbenthos (e.g. bacteria and protozoans) probably accounted for approximately twothirds of the SCOC. Epifauna (e.g. Ophiacantha bidentata) was generally rare, their oxygen uptake (median: $4 \mu \mathrm{mol} \mathrm{O} \mathrm{O}_{2}^{-2} \mathrm{~h}^{-1}$ ) was roughly $50 \%$ of that of the meiofaunal respiration and $25 \%$ of that of the endobenthic megafauna (e.g. Ctenodiscus crispatus; median: $17 \mu \mathrm{mol} \mathrm{O}_{2} \mathrm{~m}^{-2} \mathrm{~h}^{-1}$ ). Since benthic fish biomass was low, total fish respiration (median: $0.35 \mu \mathrm{mol}$ $\mathrm{O}_{2} \mathrm{~m}^{-2} \mathrm{~h}^{-1}$ ) was estimated to be more than 300 times lower than SCOC.

On the shallow banks, where strong bottom currents lead to coarse-grained and stony seabeds, megafaunal epibenthos (e.g. brittle stars) was significantly more important as an oxygen sink (Fig. 4). The median epifaunal respiration rate was $19 \mu \mathrm{mol} \mathrm{O}_{2} \mathrm{~m}^{-2} \mathrm{~h}^{-1}$. However, at locations with very high abundances of the brittle star Ophiocten sericeum, rates could even reach values $>200 \mu \mathrm{mol} \mathrm{O}_{2} \mathrm{~m}^{-2} \mathrm{~h}^{-1}$ (Table 7). Megafaunal endobenthos was significantly less important. As opposed to the relationship at the deeper stations, their total respiration (median: $4 \mu \mathrm{mol} \mathrm{O} \mathrm{m}^{-2} \mathrm{~h}^{-1}$ ) was only $25 \%$ of that of the epibenthos. Since it was not possible to measure SCOC on the shallow banks, the impor tance of this oxygen flux pathway could only be inferred from estimates of meio- and macrofaunal respiration (medians: $6 \mu \mathrm{mol} \mathrm{O}_{2} \mathrm{~m}^{-2} \mathrm{~h}^{-1}$ and $15 \mu \mathrm{mol} \mathrm{O}_{2} \mathrm{~m}^{-2} \mathrm{~h}^{-1}$, respectively), both being part of SCOC. Assuming that the median withinSCOC partitioning between micro- and meio/ macrobenthos (68:32) did not vary significantly between the 2 habitat types, the median SCOC on the shallow banks is estimated to be about $66 \mu \mathrm{mol} \mathrm{O} \mathrm{m}^{-2} \mathrm{~h}^{-1}$, thus approximately 3 times higher than the median megafaunal (endo- and epibenthic) oxygen consumption. The respiration by fish (median: $0.1 \mu \mathrm{mol} \mathrm{O}_{2} \mathrm{~m}^{-2} \mathrm{~h}^{-1}$ ) was again only a minor proportion of $\mathrm{BCOC}$.

The oxygen flux through the benthic communities differed between the 2 habitats, not only in partitioning pattern, but also in total: the median total benthic community respiration was estimated to be approximately $90 \mu \mathrm{mol} \mathrm{O}_{2} \mathrm{~m}^{-2}$ $\mathrm{h}^{-1}$ on the shallow banks and approximately $140 \mu \mathrm{mol} \mathrm{O}_{2} \mathrm{~m}^{-2} \mathrm{~h}^{-1}$ at the deeper locations (Fig. 4). If expressed as organic carbon mineralization rates, assuming a constant respiratory quotient (RQ) of 0.85 for SCOC and 0.80 for megabenthos (Smith 1978), these median respiration values are equivalent to about $21 \mathrm{mg} \mathrm{C} \mathrm{m}^{-2} \mathrm{~d}^{-1}$ on the shallow banks and about $35 \mathrm{mg} \mathrm{C} \mathrm{m}{ }^{-2} \mathrm{~d}^{-1}$ at the deeper locations.

\section{DISCUSSION}

\section{Methodology}

It is generally accepted that SCOC values obtained by sediment-water incubations of undisturbed core samples correlate well with in situ rates at water depths less than approximately $1000 \mathrm{~m}$ (Gundersen 1992). In general, the sediments in the study area were mostly oxygenated down to $25 \mathrm{~mm}$ in the sediment (Hulth et al. 1994). The relatively deep oxygen penetrations, together with the low measured rates of sulfate reduction and denitrification (Blackburn et al. unpubl., Hall et al. unpubl.), made the importance of oxidation of reduced sulfide, iron and manganese on the oxygen consumption less likely. The SCOC values presented by us (i.e. the total sediment oxygen uptake TSOC corrected for the oxygen consumed during nitrification) were, therefore, assumed to reflect exclusively the respiration of the benthos.

No SCOC data were available from core incubation measurements on the banks, because the MUC could not be employed at locations with coarse sediments. 
Therefore, SCOC in this habitat type had to be inferred from external information. We found a highly significant inverse correlation between water depths and SCOC (Fig. 3), probably reflecting the depth-related gradient in sediment deposition rate and, thus, food supply to the benthos (Hulth et al. 1994). This nonlinear power function, however, has been established for deeper sites exclusively, and its extrapolation for the lower depths of bank stations is very probably not valid. On the contrary, from the sediment properties (i.e. grain size and TOC), which were identified as major abiotic factors discriminating between shallow and deep sites, we assume that SCOC would be rather lower on the banks than in the depressions or on the slopes. Within the comparatively narrow range of grain sizes for which we measured SCOC (Table 1), no significant correlation between SCOC and both grain size and TOC was found. For a broader grain size range, however, it is known from other studies (e.g. Grant et al. 1991) that grain size is inversely correlated with SCOC because fine sediments are characterized by increased grain surface, organic content and bacterial biomass (Yamamoto \& Lopez 1985), all of which interact to enhance the metabolic activity. The assumption of a reduced sediment community metabolism was supported by our meio-and macro-infauna respiration estimates, which tended to be lower on the banks than at deeper sites, though this difference was not significant (Table 7). Because no further external data were available, we were compelled to apply parsimony and to estimate a median SCOC for the banks from the meio- and macrobenthic respiration rates, assuming that the within-SCOC partitioning was not significantly different between 'shallow' and 'deep' habitats.

For the assessment of meiofaunal oxygen consumption, we used a regression equation given by Grant \& Schwinghamer (1987) which relates total meiobenthic biovolume to total meiobenthic respiration at a temperature of $10^{\circ} \mathrm{C}$. To compensate for the well-known dependency of metabolic rates on temperature, the estimated respiration values were subsequently scaled down to lower Arctic temperatures using a $Q_{10}$ of 2 . $Q_{10}$-values describing the inter-habitat variation of biological activity rates are typically in the range of 2 to 4 (Smith 1978). Price \& Warwick (1980) reported a $Q_{10}$ of about 2 to be characteristic for meiobenthos which feed on seasonally unstable food resources - a situation which we regard as applicable to Arctic waters. The choice of higher $Q_{10}$ would not drastically alter our basic conclusions with respect to the meiofauna's share of the total benthic respiration: a $Q_{10}$ of 3 would decrease the meiofaunal respiration estimates by $30 \%$, and $a Q_{10}$ of 4 by $50 \%$.

For the estimation of macro- and megafaunal endobenthic respiration we applied different mean meta- bolic rates for polychaetes, molluscs, crustaceans, echinoderms and other taxa to account for gross metabolic differences between taxa. These rates have been assessed at low Arctic temperatures by closed-bottle measurements (K. W. Opalinski unpubl.) It is well known that the closed-bottle technique generally provides relatively high values (Clarke 1983) due to the stress-induced increase of the oxygen consumption of the organisms, especially in the first phase of each measurement. To account for this phenomenon, which is particularly obvious for polar animals with generally low routine metabolisms, the values were rounded off by 5 to $10 \%$ prior to the further calculations. We did not use allometric functions relating metabolism and average body size because all of these were established for temperatures higher than met in our study. We assumed the error due to the use of gross taxonspecific conversion factors determined for ambient temperatures to be less than if we had generally applied mass-scaled estimates, standardized using arbitrary $Q_{10}$-values. The size-dependency of metabolism was accounted for by applying metabolic rates for small macrofauna 3 times higher than for megafauna, assuming that the gross average wet body mass differ between the 2 size compartments by 2 to 3 orders of magnitude (Gerlach et al. 1985)

In contrast to SCOC, which implicitly includes the oxygen demand of the entire sediment community, the total respiration of the megabenthic epifauna was approximated by estimates for brittle stars only. The abundance and respiration values derived for the brittle stars were considered as conservative measures of the total epifaunal abundance and respiration, because brittle stars clearly dominated the epibenthos numerically: they accounted for up to $95 \%$ of the organisms visible on seabed images (Piepenburg \& Schmid unpubl.). At certain locations, however, other species (e.g. the sea urchin Strongylocentrotus pallidus) also occurred at relatively high abundances. In Agassiz trawl catches concomitantly conducted in the same study area, the share of brittle stars in the numbers of megabenthic organisms caught (besides echinoderms, crustaceans, polychaetes and bivalves) ranged between 65 and 98\% (Schmid 1994). Their share in total megabenthic respiration approximated on the basis of trawl catch numbers ranged from 20 to $94 \%$ with a mean of $47 \%$ (Schmid 1994). These findings indicate that other epibenthic species, especially motile crustaceans with relatively high individual oxygen consumption rates, can locally also be important energetically. On average, the mean megabenthic respiration may thus be underestimated by the restriction to brittle stars by a factor of 2 .

Epibenthic stock sizes were parameterized by abundance instead of biomass. Therefore, the oxygen up- 
take rates used to estimate total epibenthic respiration had to be related to individuals instead of biomass. For a precise assessment, total respiration of the various species would have to be derived by summation of the oxygen uptake of different size classes (Smith 1983, Smith et al. 1987). This approach would require the establishment of body size frequency distributions and functional relationships between body size and respiration rate - a feat which practically can not be achieved for each species at each station. Furthermore, having taken into account the narrow size range of the brittle stars, we supposed that it was sufficiently exact for the purpose of our study to evaluate the average oxygen consumption of specimens of a size near the median of the populations considered and to extrapolate to total population respiration by multiplying this value by mean abundance.

The stock size of fish could not be assessed with high precision, but had to be derived from standardized bottom trawl catches which are biased downwards to an unknown, but certainly severe degree. In addition, we applied average metabolic rates for all benthic fish species found in the study area to estimate the total fish respiration, because metabolic data were not available for each species (von Dorrien 1993). Thus, our figures are very conservative estimates, which may underestimate the true values 2 - to 10 -fold. More precise figures, however, would not drastically change our partitioning modes because fish stock size and fish respiration were comparatively low and affected the pattern of benthic oxygen flux only marginally.

Respiration rates obtained for resting megafaunal specimens in intermittent-flow measurements are assumed to reflect their standard or routine metabolism. In general, the average in situ respiration is certainly higher due to the oxygen demand of temporally changing activities (von Dorrien 1993). However, the scope of this increase is very difficult to assess and, therefore, largely unknown. Estimates range from virtually nil to $100 \%$ at maximum, strongly depending on the level of activity of the organisms studied (Winberg 1960). The respiration rates we used to estimate the population respiration were slightly raised mean standard metabolic rates. With respect to the generally sluggish behaviour of the species considered, i.e. brittle stars and benthic fish, we assumed that an addition of $20 \%$ and $50 \%$, respectively, was sufficient to account for the activity metabolism when assessing the overall in situ respiration from standard metabolic rates.

\section{Respiration partitioning}

It is known that the benthic community metabolism $(\mathrm{BCOC})$ and its partitioning depend primarily on the structure of the benthic communities (i.e. the faunistic composition and the relative abundance of mega- and macrobenthos), which in its turn is very much affected by the environmental setting (e.g. water depth, bottom temperature and sediment characteristics) of the habitat investigated (Kemp \& Boynton 1981). Grebmeier \& McRoy (1989) and Pfannkuche \& Thiel (1987) hypothesized that SCOC is primarily affected by the food supply to the benthos, hence by the patterns of sedimentation of organic matter produced in the pelagial which, in turn, is ultimately controlled by hydrography and ice cover. Grant et al. (1991) stressed the significance of sediment texture and bottom temperature.

On the banks of the northern Barents Sea shelf, epifaunal brittle stars were responsible for a considerable or locally even large share of the total benthic respiration (Fig, 4). The respiration estimates varied by 1 order of magnitude between sites (Table 7). A direct comparison to SCOC was not possible because this oxygen flux pathway could not be quantified directly on the banks due to methodological problems. It is evident, however, that the oxygen consumption of brittle stars could be, in case of mass occurrences, even greater than the highest SCOC values from the deeper stations where SCOC was presumably generally higher than on the banks (Table 7). Given the limitation that our estimation of the megabenthic respiration was confined to brittle stars and that SCOC on the banks had to be inferred from external data, our results indicate that any assessment of community oxygen uptake, which is based on SCOC measurements alone, would severely underestimate the total BCOC at locations on the shallow shelf banks.

At deeper sites, the epibenthos was considerably less important, and SCOC dominated the oxygen flux through the benthos (Fig. 4). The between-site variation of SCOC values, i.e. the spatial patchiness of SCOC, is considerably less than that of the epibenthic respiration on the banks (Table 7). Our estimates of meio- and macrobenthic respiration suggest that microbenthic oxygen uptake accounted for about twothirds of SCOC (Table 7). In contrast, Grebmeier \& McRoy (1989) and Blackburn (1987) estimated that macrofaunal respiration represented 60 to $70 \%$ of $\mathrm{SCOC}$ in the northern Bering Sea, where the seabed was characterized by relatively coarse sediments (fines $<30 \%$, Grebmeier et al. 1989) and, due to the local mass occurrence of ampeliscid amphipods and tellinid bivalves, benthic biomass and community respiration were generally higher than in the northern Barents Sea (Pfannkuche \& Thiel 1987, this study). For the more Arctic Chukchi Sea, which is generally characterized by higher proportions of fine sediments where benthic biomass and oxygen flux are lower than in the Bering Sea, Blackburn (1987) found 5 to $50 \%$ of SCOC 
to be due to macrobenthic metabolism - a partitioning pattern similar to that elucidated by us in the northern Barents Sea. These findings might indicate that the sediment granulometry primarily affects the partitioning pattern, while the benthic biomass and, thus, the quantity of the oxygen flux is primarily influenced by other factors, e.g. food supply (Grebmeier \& McRoy 1989).

Not very surprising for a high Arctic region, the total benthic oxygen consumption rates we found in the northern Barents Sea were generally low, even if SCOC is combined with the respiration of megabenthic fauna. The values were in the same order of magnitude as those assumed to be typical for upper continental slopes (i.e. 200 to $1000 \mathrm{~m}$ ) of the world ocean (Smith et al. 1987, Grebmeier \& McRoy 1989). However, Pfannkuche \& Thiel (1987) reported SCOC figures from the northern Barents Sea which were even 2 to 10 times lower. In contrast, Grebmeier \& McRoy (1989) measured SCOC rates in the Bering Sea and the Chukchi Sea which exceeded our figures by factors of 7 and 3, respectively. According to Pfannkuche \& Thiel (1987) biomass-related oxygen consumption rates estimated as SCOC were 3 to 4 times lower in the northern Barents Sea than in the eastern Atlantic, despite evidence for a similar food supply. This observation is interpreted as indication that the high benthic stocks characteristic for many polar biotopes actually consume comparatively low amounts of energy.

In the Catalina Basin off southern California, USA (1300 $\mathrm{m}$ water depth, $3.5^{\circ} \mathrm{C}$ bottom temperature, about $6.5 \%$ TOC in surficial sediments), a series of studies on benthic boundary layer metabolism was conducted which also included the quantification of the oxygen consumption of both the sediment commmunity and the megabenthos by a similar approach as we used (Smith 1983, Smith et al. 1987). The combined estimates of SCOC and megabenthic respiration (approximated by the oxygen uptake of the dominant brittle star Ophiophthalmus normani) amounted to about $31 \mathrm{mg} \mathrm{C} \mathrm{m}^{-2} \mathrm{~d}^{-1}$ (Smith et al. 1987), a value similar to the median $\mathrm{BCOC}$ assessed by us for the deeper parts of the northwestern Barents Sea. The share of the megabenthos in the total benthic community respiration ranged from about $10 \%$ (Smith 1983) to about $30 \%$ (Smith et al. 1987).

Another aspect of the benthic oxygen consumption partitioning is also distinguishable in our results: The meiofaunal biomass was considerably (25 to 600 times) lower than that of endobenthic macro- and megafauna (Tables 3 \& 4). Meiofaunal respiration, however, was generally only 2 to 3 times lower, and locally even exceeded the oxygen uptake of the larger endobenthic size class (Table 7). This contrast in the partitioning of biomass and oxygen flux among community compart- ments is a general phenomenon and elicits the size dependency of individual metabolism (Gerlach et al. 1985).

Apart from contributing directly to the benthic community respiration, large macro- or megafaunal animals can also affect the flux of energy and matter through the benthos in an indirect but important mode by bioturbation and bioirrigation (Grebmeier \& McRoy 1989, Romero-Wetzel \& Gerlach 1991, Graf 1992) or by shaping the micro-topography ('bioroughness') of the seabed (Hüttel \& Gust 1992). The effects of these activities on BCOC can hardly be quantified directly, but their significance may even exceed the importance of the macro- and megafaunal respiration in the actual energy turnover.

\section{Conclusion}

In this paper, we present total benthic oxygen flux budgets, encompassing the sediment community oxygen consumption as well as the respiration of the megafauna. This has seldom been attempted before, because it requires the assessment of the oxygen uptake of various benthic community fractions by the combination of different methodological approaches, a task which can only be achieved by the cooperation of several working groups, like during our field study in in the high-Arctic northwestern Barents Sea. A clear trend in the basic respiration partitioning was obvious from our results: in soft-bottom habitats, characteristic primarily for deeper shelf regions with weak bottom currents, the sediment community dominated the total oxygen flux, whereas on coarse-grained sediments, typical for shallow shelf banks with highly dynamic conditions, the benthic oxygen uptake was controlled to a large degree by the patchiness of locally extremely abundant megabenthic animals. Our findings thus indicate that many benthic respiration budgets, which are based exclusively on SCOC measurements, may severely underestimate the total oxygen flux, especially in biotopes where megafauna is abundant and represents an important pathway of the total benthic energy flow.

Our study also emphasizes the enormous difficulties in assessing the total benthic oxygen flux. Due to several reasons, it was not possible to compile a complete data set in the rather inhomogenous study area, and we had to rely on a number of assumptions to fill the gaps with reasonable estimates. A more accurate benthic respiration partitioning model would require attempts to examime all possible pathways at one single station. However - and this is another conclusion of our study - such complete inventories should also be performed at additional selected stations, repre- 
senting different benthic habitat types, in order to account for the spatial variability in environmental conditions, community compositions and respiration partitioning patterns.

Acknowledgements. We thank the captain and crew of RV 'Polarstern' as well as the participants of the EPOS II expedition for their help during the cruise. Thanks also to Ursula Schauer (Bremerhaven) and Hannes Grobe (Bremerhaven) for providing data on hydrography and sedimentology, respectively. The constructive comments of Tom Pearson (Tromsø), several colleagues from the Institute for Polar Ecology Kiel and 2 anonymous reviewers have improved the manuscript. We are grateful to the Polish Academy of Sciences for providing facilities for a workshop in Madralin (Poland) during which this paper has been drafted. The EPOS II study and the workshop were strongly supported by the European Science Foundation (ESF, Strasbourg) under the acronym SEAS (Study of the European Arctic Shelf). The work of the authors from Kiel was supported by a grant of the German Federal Ministry of Research and Technology (BMFT 03Г0568A) to Gotthilf Hempel (Kiel).

\section{LITERATURE CITED}

Ambrose, W. G., Leinaas, H. P. (1988). Intertidal soft-bottom communities on the west coast of Spitsbergen. Polar Biol. 8: 393-395

Asmus, H. (1982). Field measurements on respiration and secondary production of a benthic community in the northern Wadden Sea. Neth. J. Sea Res. 16: 403-413

Barnett, P. R. O., Watson, J., Conelly, D. (1984). A multiple corer for taking virtually undisturbed samples from shelf, bathyal and abyssal sediments. Oceanol. Acta 7: 399-408

Blackburn, T. H. (1987). Microbial food webs in sediments. In: Sleigh, M. A. (ed.) Microbes in the sea. Ellis Horwood, Chichester, p. 39-58

Chernova, N. V., von Dorrien, C. F., Neyelov, A. V., Saldanha, L. (1992). Benthic fish investigations. In: Rachor, E. (ed.) Scientific cruise report of the 1991 Arctic expedition ARK VIII/2 of RV 'Polarstern' Ber. Polarforsch. 115: 101-109

Clarke, A. (1983). Life in cold water: the physiological ecology of polar marine ectotherms. Oceanogr. mar. Biol. A. Rev. 21: $341-453$

Dye, A. H. (1981). A study of benthic oxygen consumption on exposed sandy beaches. Estuar. coast. Shelf Sci. 13: $671-680$

Feller, R., Warwick, R. M. (1988). Energetics. In: Higgins, R. P. Thiel. H. (eds.) Introduction to the study of meiofauna. Smithsonian Institute, Washington, DC

Gage, J. D., Tyler, P. A. (1991). Deep-sea biology: a natural history of organisms at the deep sea floor. Cambridge University Press, Cambridge

Gerlach, S. A., Hahn, A. E., Schrage, M. (1985). Size spectra of benthic biomass and metabolism. Mar. Ecol. Prog. Ser. 26: $161-173$

Graf, G. (1992). Benthic-pelagic coupling: a benthic view. Oceanogr. mar. Biol. A. Rev. 30: 149-190

Grant, J., Emerson, C. W. Hargrave, B. T., Shortle, J. L (1991). Benthic oxygen consumption on continental shelves off Eastern Canada. Cont. Shelf Res. 11 1083-1097

Grant, J., Schwinghamer, P. (1987). Size partitioning of microbial and meiobenthic biomass and respiration on Brown's
Bank, South-west Nova Scotia. Estuar. coast. Shelf Sci. 25: $647-661$

Grebmeier, J. M., Barry, J. P. (1991). The influence of oceanographic processes on pelagic-benthic coupling in polar regions: a benthic perspective. J. mar. Syst. 2: 495-518

Grebmeier, J. M., Feder, H. M., McRoy, C. P. (1989). Pelagicbenthic coupling on the shelf of the northern Bering and Chukchi Seas. II. Benthic community structure. Mar. Ecol. Prog. Ser. 51. 253-268

Grebmeier, J. M., McRoy, C. P. (1989). Pelagic-benthic coupling on the shelf of the northern Bering and Chukchi Seas. III. Benthic food supply and carbon cycling. Mar. Ecol. Prog. Ser. 53: 79-91

Gundersen, J. K. (1992). Oxygen dynamics in marine sediments studied by an in-situ microsensor technique. Ph.D. thesis, University of Aarhus

Hempel, G. (1985). On the biology of polar seas, particularly the Southern Ocean. In: Gray, J. S., Christiansen, M. E. (eds.) Marine biology of polar regions and the effect of stress on marine organisms. John Wiley \& Sons, Chichester, p. 3-34

Holeton, G. F. (1974). Metabolic cold adaptation of polar fish: fact or artefact? Physiol. Zool. 47: 137-152

Hulth, S., Blackburn, I H., Hall, P. O. J. (1994). Arctic sediments (Svalbard): consumption and microdistribution of oxygen. Mar. Chem. 46: 293-316

Hüttel, M., Gust, G (1992). Impact of bioroughness on interfacial solute exchange in permeable sediments. Mar. Ecol. Prog. Ser. 89: 253-267

Kemp, W. M., Boynton, W. R. (1981). External and internal factors regulating metabolic rates of an estuarine benthic community. Oecologia 51: 19-27

Kendall, M. A., Aschan, M. (1993). Latitudinal gradients in the structure of macrobenthic communities: a comparison of Arctic, temperate and tropical sites. J. exp. mar. Biol. Ecol. 172: $157-169$

Loeng, H. (1989). Ecological features of the Barents Sea. In: Rey, L., Alexander, V. (eds.) Proceedings of the 6 th conference of the Comité Arctique International, 13-15 May 1985. Brill, Leiden, p. 327-365

Opalinski, K. W. (1992). Evertebrate respiration measurements. In: Rachor, E. (ed.) Scientific cruise report of the 1991 Arctic expedition ARK VIII/2 of RV 'Polarstern' Ber. Polarforsch. 115: 97-100

Opalinski, K. W., Klekowski, R. Z. (1992). Metabolic adaptations to temperature in Spitsbergen invertebrates. In Opalinski. K. W., Klekowski, R. Z. (eds.) Landscape, life world and man in High Arctic. Inst. of Ecologa Publ. Office, Warszawa, p. 299-306

Opalinski, K. W., Weslawskı, J. M. (1989a). Oxygen consumption in arctic amphipods: metabolic cold adaptation. In Klekowski, R. Z., Styczynska-Jurewicz, E., Falkowski, L. (eds.) Proc. 21st Eur. Mar Biol. Symp. Ossolineum, Gdansk, p. $137-142$

Opalinski, K. W., Weslawski, J. M. (1989b). Ecology, metabolic rate and metabolic adaptations in Spitsbergen amphipods. Pol. Arch. Hydrobiol. 36: 333-350

Peck, L. S., Uglow, R. F. (1990). Two methods for the assessment of the oxygen content of small volumes of sea water. J. exp. mar. Biol. Ecol. 141: 53-62

Pfannkuche, O., Thiel, H. (1987). Meiobenthic stocks and benthic activity on the NE-Svalbard shelf and in the Nansen Basin. Polar Biol. 7: 253-266

Piepenburg, D. Juterzenka, K von (1994). Abundance, biomass and spatial distribution pattern of brittle stars (Echinodermata: Ophiuroidea) on the Kolbeinsey Ridge north of Iceland. Polar Biol. 14: 185-194 
Price, R., Warwick, R. M. (1980). The effect of temperature on the respiration rate of meiofauna. Oecologia 44: 145-148

Rachor, E. (ed.) (1992). Scientific cruise report of the 1991 Arctic expedition ARK VIII/2 of RV 'Polarstern' Ber. Polarforsch. 115, p. 1-150

Romero-Wetzel, M. B., Gerlach, S. A. (1991). Abundance, biomass, size-distribution and bioturbation potential of deepsea macrozoobenthos on the Voring Plateau (1200-1500 $m$, Norwegian Sea). Meeresforsch. 33: 247-265

Schmid. M. K. (1994). Distribution and respiration of ecologically important benthic species in the waters off Svalbard. Ph.D. thesis, University of Kiel (in German)

Scholander, P. F., Flagg, W., Walters, V., Irving, L. (1953). Climatic adaptations in arctic and tropical poikilotherms. Physiol. Zool. 26: 67-92

Schwinghamer, P., Hargrave, B., Peer, D., Hawkins, C. M. (1986). Partitioning of production and respiration among size groups of organisms in an intertidal benthic community. Mar. Ecol, Prog. Ser. 31: 131-142

Smith, K. L. (1974). Oxygen demands in San Diego Trough sediments: an in-situ study. Limnol. Oceanogr. 19: 939-944

Smith, K. L. (1978). Benthic community respiration in the N.W. Atlantic Ocean: in situ measurements from 40 to 5200 m. Mar. Biol. 47: 337-347

Smith, K. L. (1983). Metabolism of two dominant epibenthic echinoderms measured at bathyal depths in the Santa Catalina Basin. Mar. Biol. 72: 249-256

Smith, K. L., Carlucci, A. F., Jahnke, R. A., Craven, D. B. (1987). Organic carbon mineralization in the Santa Clara Basin: benthic boundary layer metabolism. Deep Sea Res. 34: 185-211

This article was submitted to the editor
Smith, K. L., Hinga, K. R. (1983). Sediment community respiration in the deep sea. In: Rowe, G. T (ed.) The sea, Vol. 8. Wiley and Sons, New York, p. 331-370

Steffensen, J. F. (1989). Some errors in respirometry of aquatic breathers: how to avoid and correct for them. Fish. Physiol. Biochem. 6: 49-59

Strömberg, J.-O. (1989). Northern Svalbard waters. In: Rey, L., Alexander, V. (eds.) Proceedings of the 6th conference of the Comité Arctique International, 13-15 May 1985. Brill, Leiden, p. 402-426

von Dorrien, C. F. (1993). Ecology and respiration of selected Arctic benthic fish. Ber. Polarforsch. 125: 1-99 (in German)

Walsh, J. J. (1988). On the nature of continental shelves. Academic Press, San Diego

Warwick, R. M. (1984). Meiofauna techniques. In: Holme. N. A., Mclntyre, A. D. (eds.) Methods for the study of marine benthos. Blackwell, Oxford, p. 217-244

Warwick, R. M., Price, R. (1979). Ecological and metabolic studies on free-living nematodes from an estuarine mudflat. Estuar. coast. mar. Sci. 9: 257-271

Weslawski, J. M., Wiktor, J., Zajaczkowski, M., Swerpel, S. (1993). Intertidal zone of Svalbard: 1. Macroorganism distribution and biomass. Polar Biol. 13: 73-79

Winberg, G. G. (1960). Rate of metabolism and food requirements of fishes. Fish. Res. Bd Can. Transl. Ser. 194: 1-253

Wintzell (1918). De Scandinaviska Ophiuriderna: biologi och fysiologi. Appelbergs Boktryckeri Aktiebolag, Uppsala

Yamamoto, N., Lopez, G. (1985). Bacterial abundance in relation to surface area and organic content of marine sediments. J. exp. mar. Biol. Ecol. 90: 209-220

Zenkevitch, L. (1963). Biology of the seas of the USSR. George Allen \& Unwin, London

Manuscript first received: July 18, 1994

Revised version accepted: December 14, 1994 